\title{
The Learning Center for Excellence Creativity, Entrepreneurship, and Leadership (ExCEL) in Higher Education: A Conceptual Model
}

\author{
Sisca Eka Fitria \\ School of Economic and Business, Telkom University, \\ Bandung, Indonesia \\ sekafitria@yahoo.com \\ Mediany Kriseka Putri \\ School of Economic and Business, Telkom University, \\ Bandung, Indonesia \\ mediany.kris@gmail.com
}

\author{
Grisna Anggadwita \\ School of Economic and Business, Telkom University, \\ Bandung, Indonesia \\ grisnamailbox@yahoo.co.id \\ Hani Gita Ayuningtias \\ School of Economic and Business, Telkom University, \\ Bandung, Indonesia \\ $\underline{\text { hani.gita@gmail.com }}^{4}$
}

\begin{abstract}
Learning Center for Excellence Creativity, Entrepreneurship, and Leadership (ExCEL) is an organization formed to develop students of higher education environment in innovation, entrepreneurship, and leadership. Higher education is a place to create and develop new entrepreneurs; to support this purpose an organization is needed to develop the entrepreneurial spirit, especially for students. ExCEL aims to give development facilities such as trainings, consultations, varieties of management topics for students who have interests in entrepreneurship. This research assesses the importance of ExCEL in an institution and business process which can be implemented to establish ExCEL. Moreover, to identify the intentions and needs of students, the writers distributed questionnaires to students of School of Economic and Business, Telkom University, Indonesia. 200 students participated in filling out these questionnaires. This study produced a conceptual model for the development of entrepreneurship centre in higher education. This research is expected to be a reference for higher education to establish an entrepreneurship study centre.
\end{abstract}

Keywords - Conceptual Model, Creativity, Entrepreneurship, Entrepreneurship Center, ExCEL, High Education, Leadership.

\section{INTRODUCTION}

Entrepreneurship is a process in producing ideas and creations which are embodied in a form of economic activity. The Indonesian government realizes the importance of entrepreneurial activities as one of the efforts to increase the community's economy as entrepreneurship can create jobs and decrease the number of unemployment. A country is considered prosperous when the number of entrepreneurs is at least $2 \%$ of the population; this definitely has impacted the economy's growth of a country [1]. Meanwhile, in Indonesia the number of entrepreneurs in 2015 is only $1,56 \%$, a number still far from ideal [2]. Thus, the government of Indonesia is encouraging entrepreneurship programs with several governments program, one of them is the national entrepreneurship movement. This program was established in
2011, and until now it has generated new entrepreneurs with an increase of entrepreneurs in 2013 to $1,65 \%$; however, this number is not yet adequate when compared to the standard number of entrepreneurs in a country.

According to World Bank surveys, the number of entrepreneurs in several ASEAN countries, for example Singapore, has reached $7,2 \%$, in Thailand $4,1 \%$, and in Malaysia 4\% [3]. From the population demography, Indonesia has big potentials to generate new entrepreneurs. The ministry of cooperatives and small medium enterprises (SME) has also promoted entrepreneurs growth through a program called National Entrepreneurship Movement (NEM) which is in its third year. Several programs from other government institutions are Entrepreneurship Students Program (ESP) and Entrepreneurship and Students Creativity Program (ESCP) from DIKTI (Directorate of Higher Education). With these programs, the government is optimistic that the target number of $2 \%$ entrepreneurs can be reached.

An education institution is a place to produce the nations next generation who have knowledge in each field; thus, an education institution has a big role in the formation of students' entrepreneurship spirit. The School of Economic and Business of Telkom University is one of the best education institutions in Indonesia; it offers variations of education programs which can create new entrepreneurs in many fields, especially management and technology. Students' creativity can be directed to make new entrepreneurs. Telkom University is committed to creating entrepreneurs who are expert in their fields; this in line with one of the university's purposes which is creating entrepreneurship spirit in the academic society. In the curriculum of School of Economic and Business of Telkom University there is a subject called Entrepreneurship, where students are encouraged to create business ideas and build a business; however, only selected ideas can be made into real businesses due to the short amount of time. Thus, 
there are many ideas with entrepreneurship potentials to be developed that are neglected. Based on this phenomenon, students need to develop their business ideas into real business and become entrepreneurs who have soft skills, and thus a further study is needed to initiate the formation of entrepreneurship centre in Economic and Business at Telkom University.

The centre for Excellence Creativity, Entrepreneurship, and Leadership (ExCEL) is a form of support from the Higher Education, especially Telkom University in the effort of supporting the government's program to create new entrepreneurs. ExCEL was established as a place to encourage the development of entrepreneurial culture in higher education which is supported by facilitators from higher education academics and practitioners. ExCEL gives the facility to students in all science and social disciplines to develop the intention and abilities in entrepreneurship. The output of this centre is to create young entrepreneurs who are ready and capable in their fields. Based on the importance of this learning centre, this research is conducted to further analyze the importance of establishing learning centers in higher education with the study case of Telkom University.

\section{LITERATURE REVIEW}

Entrepreneurship comes from entrepreneur which means ability to be creative thinking and have innovative behavior that are basic of that, resources, driving purpose, strategy tips and processes to meet the challenges of life [4].

Entrepreneurial intention is defined as the search for information that can be used to help fulfill the goal of venture creation [5]. It is also stated that Entrepreneurial intention is a person's motivation to make a conscious plan to perform the behavior of setting up a business. In addition, it is explained that the entrepreneurial intention is self-acknowledged conviction by a person, in that they intend to set up a new business venture and consciously plan to do so at some point in the future [6]. Therefore, the entrepreneurial intention is not just a yes or no but can be made based on the intervals of the stated intention to start a business with very low, zero or even very high levels.

It is stated that the higher a person's intention, the more likely a person does a particular behavior [7]. That links very well to the general rule defined by Ajzen Icek: The stronger the intention is, the more probable the behavior is [7]; hence, the entrepreneurial intentions function as a mediator or catalyst for entrepreneurial actions.

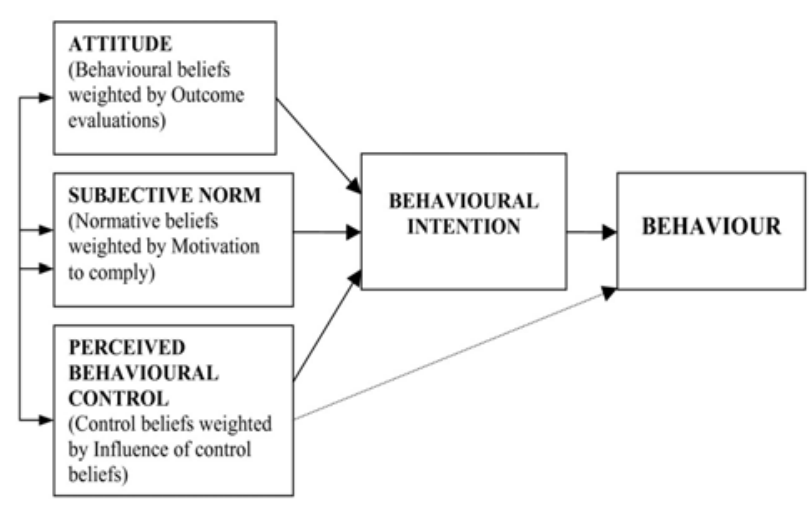

Fig. 1. Theory of Planned Behaviour [7]

Understanding the factors that trigger entrepreneurial intentions has occupied much of the entrepreneurship literature. Previous research on the factors that influence the decision to start a new business was focused primarily on personality traits [8]. Yet, entrepreneurship literature has not identified a unique set of personality traits that characterize the entrepreneur [9]. Studies have, therefore, focused on Ajzen's (1991) theory of planned behaviour (TPB) and Shapero and Sokol's (1982) entrepreneurial event (SEE) model to understand the drivers of entrepreneurial intentions (Souitaris et al, 2007). Drawing insights from the TPB, attitudes towards entrepreneurship, subjective norms and perceived behavioural control have been identified as antecedents of entrepreneurial intentions [10].

Entrepreneurship has long been described as an act of creativity [11]. Schumpeter (1934) was one of the first to propose that opportunities are created when new resource combinations result in superior products, services or processes. Yet recognizing and developing new opportunities rely on individuals' ability to see new connections between ideas or concepts 12]. The entrepreneurial cognition literature has sharpened our understanding on the cognitive properties that help individuals to become alert to and recognize opportunities [13]. Creativity has been featured as playing a key role in this process [14]. Creativity is a broad term that has received different conceptualizations in diverse fields, such as art, music, science, education, advertising and management [15]. In entrepreneurship studies, Amabile's (1996) definition of creativity (the production of novel and useful ideas) is often adopted, since 'novel and useful ideas are the lifeblood of entrepreneurship' [16].

\section{RESEARCH MethodOlOGY}

Total population of this research is students taking the subject of entrepreneurship 1 and entrepreneurship 2, which are approximately 900 people. This research used Slovin formula to set the number of respondents as sample [17]. 


$$
\mathrm{n}=\frac{N}{1+N e^{2}}
$$

$\mathrm{n}$ : number of population

$\mathrm{N}$ : total population

e : error tollerance

TABLE I. SAMPLES

\begin{tabular}{|c|c|c|c|}
\hline Subject & Total Population & No of Sample & Round Off \\
\hline Entrepreneurship 1 & 450 & 81.81 & 82 \\
\hline Entrepreneurship 2 & 450 & 81.81 & 82 \\
\hline Total & $\mathbf{9 0 0}$ & $\mathbf{1 6 3 . 6 3}$ & $\mathbf{1 6 4}$ \\
\hline
\end{tabular}

Based on the formula above, $\mathrm{n}$ is the number of samples, $\mathrm{N}$ is the population, and e is the error tolerance limit. For the subject Entrepreneurship 1 and Entrepreneurship 2 the number of samples is 82 respondents (450 populations) and the degree of error is $10 \%$. The total samples of the two subjects are 164 respondents, but the research used 200 respondents. We want to measure each subject before making an overall analysis. We used non-probability sampling based on the convenience. This method was based on the limitation in time, place, and condition [17]. We tried to considerably accommodate the population by distributing the questionnaire through the entire students who were taking the subjects Entrepreneurship 1 and Entrepreneurship 2.

As the goal of this research is to measure the influence of one independent variable towards one dependent variable, we use multiple regression methods using SPSS. Multiple regression analysis is a statistical technique which can be used to analyze the relationship between a single dependent variable and several independent variables. The objective of the multiple regression analysis is to use the independent variables whose values are known to predict the single dependent value [19]. Before using the data to measure the multiple regressions we also analyzed the validity and the reliability of the data. Using data analysis in SPSS, we found that the $\mathrm{t}$ calculate is bigger than the table (1.6635 for the Entrepreneurship 1 and 1.6639 for Entrepreneurship 2). This means the items in the questionnaire have met the validity test. SPSS data analysis shows that items in the questionnaire also pass the reliability test. The reliability test for the independent variable Entrepreneurship 1 shows 0.870 and for the dependent variable shows 0.740 . The Entrepreneurship 2 result shows 0.820 for the independent variable and 0.880 for the dependent variable. These mean all of them are above 0.70 , which is the standard for the reliability [20].

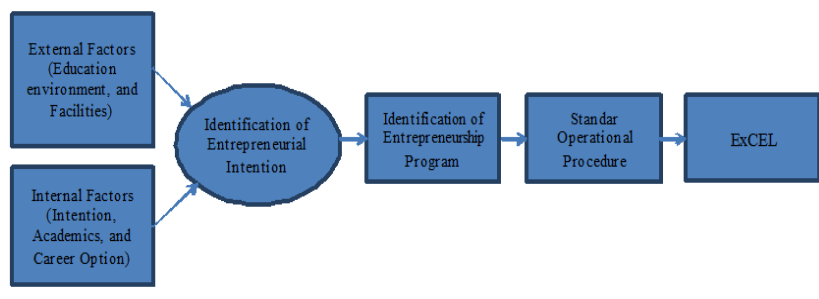

Fig. 2. Conceptual Model

\section{DATA ANALYSIS AND DISCUSION}

\section{A. Respondent's Profile}

TABLE II. RESPONDENT'S PROFILE

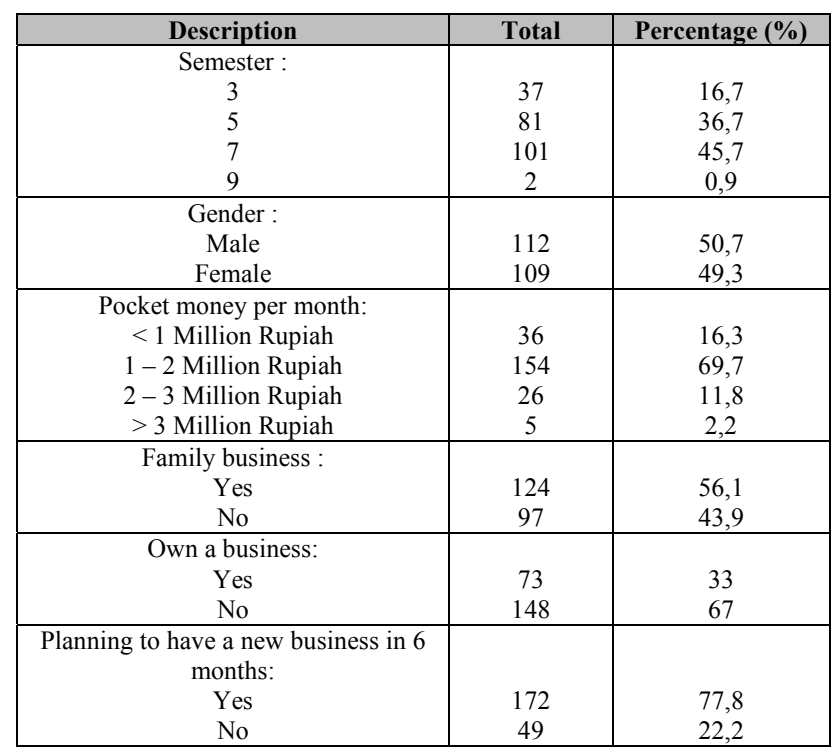

Respondents are students who have taken or were taking Entrepreneurship subjects. They were students in semester 3, 5, 7 and 9, whereas students in semester 7 were $45,7 \%$, and the least of all was students at semester $9,0,9 \%$. The male students were dominating this research by $50,7 \%$, while the female was $49,3 \%$ persen. The monthly pocket money varies with the biggest percentage of 69,7 , students with pocket money with 1-2 million Rupiahs per month. Many families of the students have already got their own business; this can be seen from the amount of family business percentage, which is $56,1 \%$. However, there are still many students who have not got their own business because students who already have businesses are $33 \%$ and students who have not are $67 \%$. $77,8 \%$ of students who have taken Entrepreneurship subjects want to have their own business in 6 month, and only $22,2 \%$ students do not plan to have their own businesses.

\section{B. ExCEL Activities}

In ExCEL activities diagram prospective entrepreneurs are the output of Entrepreneurship Student Creativity Program from DIKTI every year, but they can also exist from internal campus activities through competitions and contests to gain 
ideas or new business opportunities. Only then the functions of ExCEL as a business incubator can be conducted through its main activities, which are:

1. Consultation and Coaching Process

2. Research and Development of Business Opportunities

3. Trainings and Facilitations

4. Collaborations Opportunities

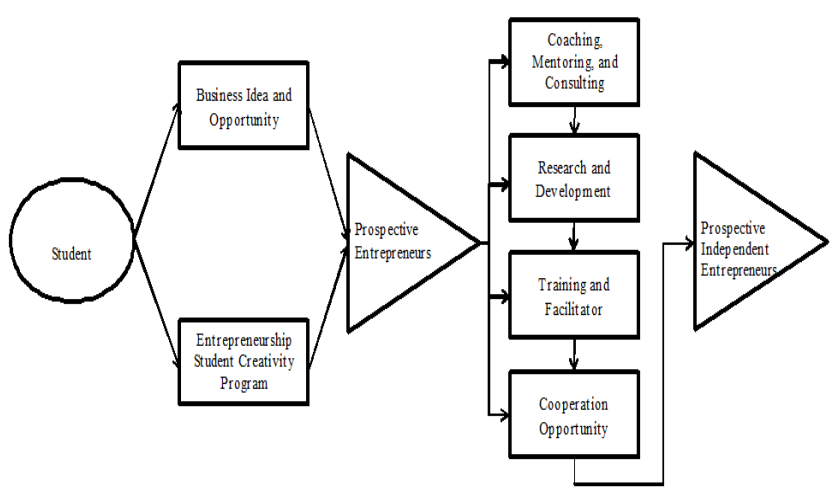

Fig. 3. ExCEL Activities

These four activities are expected to help students in running their own businesses and from this business incubator students can become independent entrepreneurs.

\section{Student Entrepreneurship Program}

TABLE III. STUDENTS PERCEPTION

\begin{tabular}{|c|c|c|c|c|c|}
\hline \multirow{2}{*}{$\begin{array}{c}\text { VARLABLE } \\
\text { SUBVARLABEL }\end{array}$} & \multirow[t]{2}{*}{ INTENTION } & \multicolumn{2}{|c|}{ INTERNAL FACTOR } & \multicolumn{2}{|c|}{ EXTERNAL FACTOR } \\
\hline & & COMPET ENCE & CAREER OPIION & $\begin{array}{l}\text { EDUCATION } \\
\text { ENVIRONMENT }\end{array}$ & FACUIIES \\
\hline \multicolumn{6}{|l|}{ SCAIE } \\
\hline Very Disarrement & $459 \%$ & $0,65 \%$ & $1,36 \%$ & $0,90 \%$ & $1,73 \%$ \\
\hline Disgarement & $7,30 \%$ & $4,16 \%$ & $3.85 \%$ & $2,71 \%$ & $14,67 \%$ \\
\hline Netral & $20,23 \%$ & $33,76 \%$ & $29,86 \%$ & $32439 \%$ & $45,14 \%$ \\
\hline Agge: & $28,35 \%$ & $46,52 \%$ & $39,37 \%$ & $45,25 \%$ & $32,64 \%$ \\
\hline Verv Agree & $39,30 \%$ & $14,93 \%$ & $2557 \%$ & $1870 \%$ & $582 \%$ \\
\hline
\end{tabular}

Respondents very much agree to have entrepreneurial intentions and only $4,59 \%$ disagree. In internal factors variables with sub variables of competency with $46,52 \%$ respondents who agree that they have the competency to become entrepreneurs, only $0,63 \%$ respondents disagree. For sub variable of career option, $39,37 \%$ agree to make entrepreneurs as their career option, and only $1,36 \%$ very much disagree. In the variable of external factors, sub variable of education environment, 45,25\% agree that education environment is helpful in becoming entrepreneurs, and only $0,90 \%$ disagree. While for sub variable of utilities and facilities, $45,14 \%$ respondents are doubtful about the availability of utilities and facilities can help students in practicing entrepreneurship.

\section{CONCLUSION}

Based on the assessment above, it can be seen that students have intentions to be entrepreneurs and they have the competencies and options in career as internal factors which support their intentions. However, it is only education environment as the external factor that supports to be entrepreneurs, while the existing utilities and facilities were not adequate for supporting their entrepreneurial activities. A further research is needed to test the causal relationship between variables as this has not yet been conducted. Also, a further study is needed to initiate the establishment of entrepreneurship centre in Telkom University. The entrepreneurship centre has an important role as a place to develop the talent and entrepreneurial intentions of students. This centre is expected to support the Indonesian government program to increase the number of entrepreneurs in Indonesia. Furthermore, the entrepreneurship centre is a real form to prepare students to face global competitions, especially the ASEAN Economic Society (AES) in 2015. The liberalization of economy will force students to have ideas and creativities, especially in the creation of a new business. Seeing how important an entrepreneurship centre in higher education is, it is essential that higher education in Indonesia encourage the formation of assessment and research to establish an entrepreneurship centre.

\section{References}

[1] McClelland, D. C. The achieving society. Princeton, NJ: Van Nostrand, 1961.

[2] Kementrian Koperasi dan UMKM. Wirausaha Maju, Negara Sejahtera. [Online],

http://www.depkop.go.id/index.php?option=com content\&view=article \&id=1521: wirausaha-maju-negara-sejahtera\&catid=54:bind-beritakementerian\&Itemid=98, 20 March 2015. [Retrieved on September 2015]

[3] Baron, R. A. (2004), 'The cognitive perspective: a valuable tool for answering entrepreneurship's basic "why" questions', Journal of Business Venturing, Vol 19, pp 221-239.

[4] Wibowo, Muladi. 2011, Pembelajaran Kewirausahaan dan Minat Wirausaha Lulusan SMK, Explanasi Volume 6 Nomor 2 Edisi September, halaman 93-103

[5] Bird, B. 1988. Implementing entrepreneurial ideas: The case for intentions. Academy ofManagement Review 13:442-454.

[6] Lorz, Michael. 2008, The Impact of Entrepreneurship Education on Entrepreneurial Intention, Dissertation of the University of St. Gallen, School of Management, Economics, Law, Social Sciences and International Affairs.

[7] Ajzen, I. 1991.Theory of planned behavior. Organizational Behavior and Human Decision Processes 50:179-211.

[8] Low, M. B., and MacMillan, I. C. (1988), 'Entrepreneurship: past research and future challenges', Journal of Management, Vol14, pp 139161.

[9] Shaver, K. G. (1995), 'The entrepreneurial personality myth',B\&E Review, April-June, pp 20-23.

[10] Krueger, N.F./Reilly, M.D./Carsrud, A.L. (2000): Competing Models of Entrepreneurial Intentions; in: Journal of Business Venturing 15, No. 5-6 (2000), pp. 411-432

[11] Schumpeter, J. A. (1934), The Theory of Economic Development: An Inquiry into Profits, Capital, Credit, Interest, and the Business Cycle, Harvard University Press, Cambridge, MA.

[12] Davidsson, P. (2002), 'What entrepreneurship research can do for business and policy practice', International Journal Entrepreneurship Education, Vol 1, pp 5-24.

[13] Baron, R. A. (2004), 'The cognitive perspective: a valuable tool for answering entrepreneurship's basic "why" questions', Journal of Business Venturing, Vol 19, pp 221-239. 
[14] Hills, G. E., Shrader, R. C., and Lumpkin, G. T. (1999), 'Opportunity recognition as a creative process', Frontiers of Entrepreneurship Research, pp 216-227.

[15] El-Murad, J., and West, D. C. (2004), 'The definition and measurement of creativity: what do we know?' Journal of Advertising Research, June, pp 188-201.

[16] Ward, T. B. (2004), 'Cognition, creativity and entrepreneurship', Journal of Business Venturing, Vol 19, pp 173-188.

[17] Prasetyo, Bambang, \& Jannah, Lina Miftahul. (2005). Metode Penelitian Kuantitatif, Teori dan Aplikasi. Jakarta:PT. Raja Grafindo.

[18] Hair, Joseph., Black, William.,Babin, Barry., Anderson, Rolph.2010. Multivariate Data Analysis.Pearson Prentice Hall

[19] Sugiyono. (2011). MetodePenelitianKuantitaif, Kualitatif, danRiset. Bandung: Alfabeta 